\title{
Obtaining biodegradable polymeric membrane from agroindustrial wastes using the electro-spinning method
}

\section{Obtención de membrana polimérica biodegradable por el método de electrohilado a partir de residuos agroindustriales}

Elizabeth Presenda-Gerónimo ${ }^{1}$, Alfredo Maciel-Cerda ${ }^{2}$, Ricardo Vera-Graciano ${ }^{2}$, Gloria Ivette Bolio-López ${ }^{1}$, Manuel Mateo Hernández-Villegas ${ }^{1}$, Liliana Pelayo-Muñoz ${ }^{1}$, María Teresa CadenasGonzález $^{1 *}$

${ }^{1}$ Universidad Popular de la Chontalpa. División Académica de Ciencias Básicas e Ingeniería, Carr. Cárdenas-Huimanguillo Km. 2, Ra. Paso y Playa. C.P. 86556. Cárdenas, Tabasco. ${ }^{2}$ Universidad Nacional Autónoma de México. Instituto de Investigaciones en Materiales. Laboratorio de Ingeniería de tejidos. Av. Universidad 3000, Copilco, Cd. Universitaria, C.P.04510. Ciudad de México, D.F.

*Corresponding author.

E-mail address: maythecg@gmail.com (M. T. Cadenas-González).

Article history:

Received: 13 December 2016 / Received in revised form: 12 June 2017 / Accepted: 28 June 2017 / Published online: 1 July 2017.

https://doi.org/10.29267/mxjb.2017.2.2.232

\begin{abstract}
Sugarcane straw is a waste beneficial to man when used correctly. Its burning is highly destructive if carried out indiscriminately; it causes damage to the soil and emits charcoal particles that pass directly into the environment. Cellulose represents approximately onethird of its composition and is biosynthesized in the process of photosynthesis, producing about 1000 tons per year in the world. In recent years, the electro-pile technique is widely used for the production of polymer fibers with nanometer-to-micrometer diameters. This diameter size allows obtaining materials with large surface area, a desirable feature in the manufacture of membranes with potential application in separation and biomedical processes. The technique is versatile and easy to assemble which has allowed to process a great variety of polymers, integrating in the last years other kinds of materials, nevertheless during the development of the process exist a series of variables that influence in the characteristics of the obtained elements, Either because they are linked to the characteristics of the base material or because their performance is related to other parameters within the process. The objective of this research was to obtain biodegradable polymer membranes from sugar cane being attractive at the biotechnological level.
\end{abstract}

Keywords: Cellulose, Electro-spinning, Membrane. 


\section{RESUMEN}

La paja de la caña de azúcar es un residuo beneficioso para el hombre cuando se usa correctamente. Su quema es altamente destructiva si se realiza indiscriminadamente, genera daños al suelo y emite partículas de carbón vegetal que pasan directamente al medio ambiente. La celulosa representa aproximadamente un tercio de su composición y es biosintetizada en el proceso de fotosíntesis, produciendo alrededor de 1000 toneladas por año en el mundo. En los últimos años, la técnica de electrohilado es muy utilizada para la producción de fibras poliméricas con diámetros en escala nanométrica a micrométrica. Este tamaño de diámetro permite obtener materiales con gran área superficial, característica deseable en la fabricación de membranas con aplicación potencial en procesos de separación y biomédicas. La técnica es versátil y de fácil ensamble lo que ha permitido procesar una gran variedad de polímeros, integrando en los últimos años otras clases de materiales, sin embargo durante el desarrollo del proceso existen una serie de variables que influyen en las características de los elementos obtenidos, ya sea porque están ligadas a las características del material base o porque su desempeño está relacionado con otros parámetros dentro del proceso. El objetivo de esta investigación fue obtener membranas poliméricas biodegradables de caña de azúcar siendo atractivas a nivel biotecnológico.

Palabras clave: Celulosa, Electrohilado, Membrana.

\section{INTRODUCTION}

Cellulose, as a support, is the main component of cell walls of plants and the carbohydrate most widely spread. Vegetable fibers, such as cotton, jute, flax, hemp and ramie, are practically cellulose (Beyer \& Walter, 1999). The general formula of cellulose can be written as that of starch $\left(\mathrm{C}_{6} \mathrm{H}_{10} \mathrm{O}_{5}\right) n$ but here the numerical value of $\mathrm{n}$ is much greater. Studies carried out by methylation show that, unlike starch, the structure of cellulose is mostly unbranched (Linstromberg, 2006).

Unlike starch, the D-glucose molecules are bound in the B $(1,4)$-glucoside form, which is due to the different properties of cellulose. The chains form long chains due to the fluctuating spatial arrangement of hydrogen bridges, which are joined in the form of a beam (X-ray structural analysis) (Beyer \& Walter, 1999). The straight chain formed by the B bonds is optimal for the construction of fibers with high tensile strength (Berg et al., 2008). Cellulose was the first polymeric material that was chemically modified to obtain new polymers of commercial interest. The hydroxyl groups of the cellulose possess the reactivity of the alcohols. As a consequence, when the cellulose is treated with excess of acetic anhydride in acetic acid with a little sulfuric acid as the catalyst is converted into its acetate. Similar modifications of the cellulose allow its use in a wide variety of commercial products. These modifications of the cellulose involve the conversion of the hydroxyl groups into other functional groups. In the process, the cellulose molecule is partially degraded and its dissolution is more likely. In this soluble state it is transformed into thin sheets or strands, and when other solvents are added to re-precipitate or it becomes the initial chemical reaction (Ege, 2000).

Nanofibers are a thin, elongated object in the form of a wire that is found on nanometer scale $\left(10^{-9} \mathrm{~m}\right)$. Due to their characteristics, nanofibers have been studied in medical science; 
researchers have focused on the application of nanofibers to filtration, drug delivery, tissue engineering, and wound healing. Can be processed through five main processes: Drawing, Synthesis with platilla, Phase separation, Self-assembly and Electro-spinning. Electrospinning is a process to form nanometer-to-micrometer diameter fibers, whose basic principle is to apply a high voltage (between $5 \mathrm{kV}$ and $30 \mathrm{kV}$ ) to a polymer solution which, when charged electrically, is deformed into threads which are interlaced when directed towards an area of lower potential, which is generally connected to ground (Young et al., 2009; Siil, 2008).

However, in such studies, a significant problem arises in polymer selection (Ciechanshka, 2004; Prashanth \& Tharanathan, 2007). Specifically, there is a wide range of spinnable polymers; however, only a few of them have the necessary parameters to make them suitable for use in such critical applications.

The organic or polymeric membranes constitute the most extensive and developed field of the membranes, both from the point of view of manufacturing volume and from the field of possible applications. The possible reason that has led to this situation has to do with the characteristic versatility of polymers that have made them also essential in other technological and industrial applications and which can be summarized:

1. There is the possibility of exerting some control over the molecular configurations of the polymers, which affects the permeability and selectivity of the membranes.

2. Polymers can easily adapt different physical forms which mean an advantage in the technological field.

3. The great variety of existing polymers allows choosing the most interesting ones to design a certain membrane.

This process is commonly applied to various types of polymers (Huang et al., 2003), and nanocompounds of biopolymers based on proteins and polysaccharides, alone or in combination, such as zein (Li et al., 2002), wheat proteins (Smith, 2004), sodium alginate/ Pectin (Khil et al., 2005), gelatin/sodium alginate and zein/chitosan (Li et al., 2008). However, the literature on the manufacture of nanoprobes of biopolymers is limited, since their production is usually more difficult in relation to that of synthetic polymers (Jiang et al., 2005).

Food science has shown a specific interest in the production of nanofibers from biodegradable and biocompatible polymers in response to the need to develop packaging materials with improved mechanical properties and barrier and by the demand for better performance of the systems. Microencapsulation (Dersch et al., 2005). On the other hand, nanofibers, by their dimensions, offer the potential to significantly improve the solubility and bioavailability of many functional ingredients as well as controlled release behavior (Yun et al., 2007).

\section{MATERIALS AND METHODS}

The biological material straw samples were collected from mature sugarcane plantations (Saccharum officinarum), was collected from the municipality of Huimanguillo, the region of Chontalpa, Tabasco state of México. 


\subsection{Preparation of the sample}

Cazaurang method is used to obtain the cellulose sample, which consists of the following steps (Cazaurang et al., 1990):

Pre-treatment. In order to eliminate waxes, pectins and resins present in raw material. Heat 31 of $10 \% \mathrm{NaOH}$ in a batch with stirrer until boiling. It will be heated in a thermo park plate to $400{ }^{\circ} \mathrm{C}$ once the first bubble is observed, it will be left $10 \mathrm{~min}$. The sample will be washed with running water 5 times and then with purified water (regulated with $\mathrm{pH}$ 7) until it reaches $\mathrm{pH}$ 7. The sample will be squeezed and crumbled on an aluminum tray, then dried in a forced air oven at $65^{\circ} \mathrm{C}$ for 12 hours and the dry weight will be recorded.

Hydrolysis. This is to eliminate the amorphous regions of cellulose. $20 \mathrm{~g}$ of the pre-treated fiber is then placed with $0.4 \% \mathrm{H}_{2} \mathrm{SO}_{4}$ and once boiled it is covered for one hour with shaking every 20 minutes. The sample shall be heated to $400{ }^{\circ} \mathrm{C}$. Once the solution is boiled, the container will be counted for one hour. At the end of the time, it will be allowed to stand for 10 minutes to cool down and seven washings will be carried out with purified water.

Chlorination. In this step, lignin is degraded and the size of the cellulose is reduced. It is carried out with stirring at $600 \mathrm{rpm}$ in $3.5 \% \mathrm{NaClO}$ then in a water bath at $30{ }^{\circ} \mathrm{C}$ for 10 minutes.

Alkaline extraction. Solubilizes the hemicellulose. Samples are placed in a $\mathrm{NaOH}$ solution at a concentration of $20 \%$ and stirred manually for 10 minutes and then at $600 \mathrm{rpm}$ for 1 hour, afterwards, 12 washings with purified water will be carried out until the $\mathrm{pH}$ reaches neutral.

Whitening. A $0.5 \% \mathrm{NaClO}$ is used, this to remove lignin residues and chromophoric components. It was homogenized with a glass stirrer manually for 1 hour. Subsequently, 6 wash with purified water. This will give the cellulose white. It will be placed in flatbottomed aluminum trays and left to stand for 24 hours in the room. It is then dried in a forced air oven at $65^{\circ} \mathrm{C}$ for 24 hours (Fig. 1).

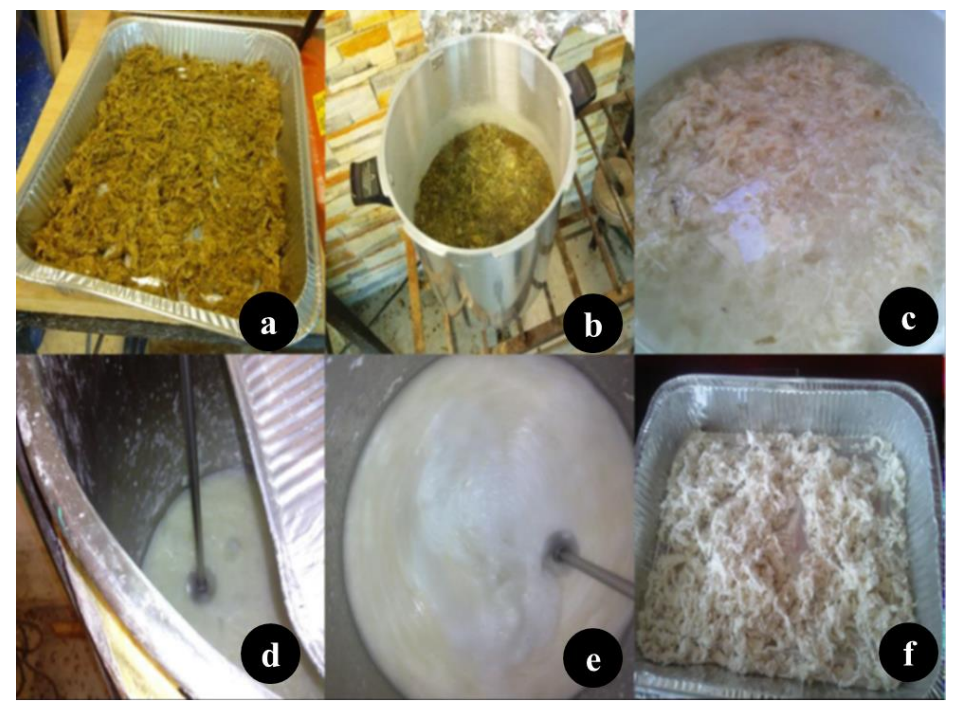

Fig. 1. Cazaurang method: a) Pretreatment, b) Hydrolysis, c) Chlorination, d) Alkaline extraction, e) Whitening, f) Cellulose obtained. 


\subsection{Preparation of solutions}

A solvent for solubilizing cellulose, some of which are: Urea $+\mathrm{NaOH}$, Trifluoro ethanol, hexafluoride-isopropanol and Trifluoroacetic acid, maintaining a temperature of $40-70{ }^{\circ} \mathrm{C}$, a high molecular weight and suitable concentrations in each of the solutions until the cellulose samples were dissolved, $0.5 \mathrm{~g}$ of cane cellulose was placed, this was postponed, because when placing the whole amount of cellulose the solution was very viscous, so that every 30 minutes cellulose was added at $5 \mathrm{Ml}$ solvent to the optimum concentration. Even at very low concentrations such as $2.5 \%, 3.3 \%$ and $5 \%$, we find too much viscosity to electrolyte immediately.

Solutions lower than $2 \% \mathrm{w} / \mathrm{v}$ were prepared, however, in this way we obtained a low percentage of cellulose, so that the samples with the highest concentration were allowed to degrade to finally electro-spin.

\subsection{Process of electro-spinning technique}

For the electro-spinning the equipment with the following characteristics was used:

1. New Era Pump, Pump Inc. Syringe Pump Model NE-1600

2. Power source brand Glassman High Voltage Inc. Model EH

3. Hydrometer

4. Acrylic box with Drierite desiccant brand Sigma-Aldrich (calcium sulphate and Gypsum)

The technique consists of rotating polymer solutions through high electric fields, is based on applying sufficient electrical forces that exceed the forces of the surface tension in the polymer solution loaded, thus at a given voltage, fine jets of solution Are expelled from the capillary to the manifold plate. Subsequently the jet moves in the direction of the electric field, elongating according to external and internal forces and experiencing instability on some occasions. The solvent is evaporated and the fiber segments are randomly deposited on a substrate (Huang et al., 2003).

The process consisted, in its simplest form, of a container containing the polymer solution, two electrodes (the first connected to the solution vessel and the second connected to the manifold), a power supply and a manifold. The solution was drawn by high voltage from the vessel by forming an electrically charged jet into the manifold by decreasing its diameter to form a continuous fiber interlacing (Fig. 2).

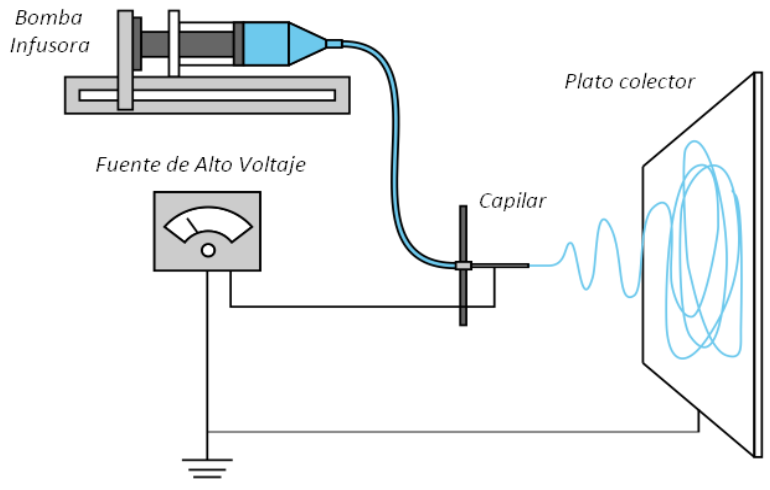

Fig. 2. Assembly of the electrospinning system. 
Some important characteristics for electro-spinning are:

- Have a solvent that completely dissolves the polymer.

- The vapor pressure must be such that it evaporates completely before the fiber reaches the collector but late enough to reduce the size of the fiber on a nanometer scale.

- Viscosity and surface tension must be low so that the electric field can deform the solution, but high enough to prevent the solution from spilling from the container.

- The power source must generate an electromagnetic field strong enough to overcome the surface tension and viscosity of the solution.

- The distance between the container and the manifold should not be small enough to form an electric arc or spark but large enough for all the solvent to evaporate.

Electro-spinning depends on important parameters such as: voltage, distance from the collector plate to the needle, the injection flow, the voltage needed to achieve electrospinning, as well as temperature and humidity (Sill \& Recum, 2008).

\section{RESULTS}

\subsection{Fiber performance}

Sugarcane cellulose was obtained after following the Cazaurang method, using the variety Mex-69-290. The process of obtaining cane straw cellulose by this method allowed obtaining a percentage of cellulose of $43 \%$ (Fig. 1).

The cane samples were taken to a drying oven for two days because of the large percentage of moisture contained, $1750 \mathrm{~g}$ were weighed. After drying, $760 \mathrm{~g}$ of sugarcane straw were obtained. Finally, it was obtained $220 \mathrm{~g}$ of cellulose with the Cazaurang method (Fig. 3).
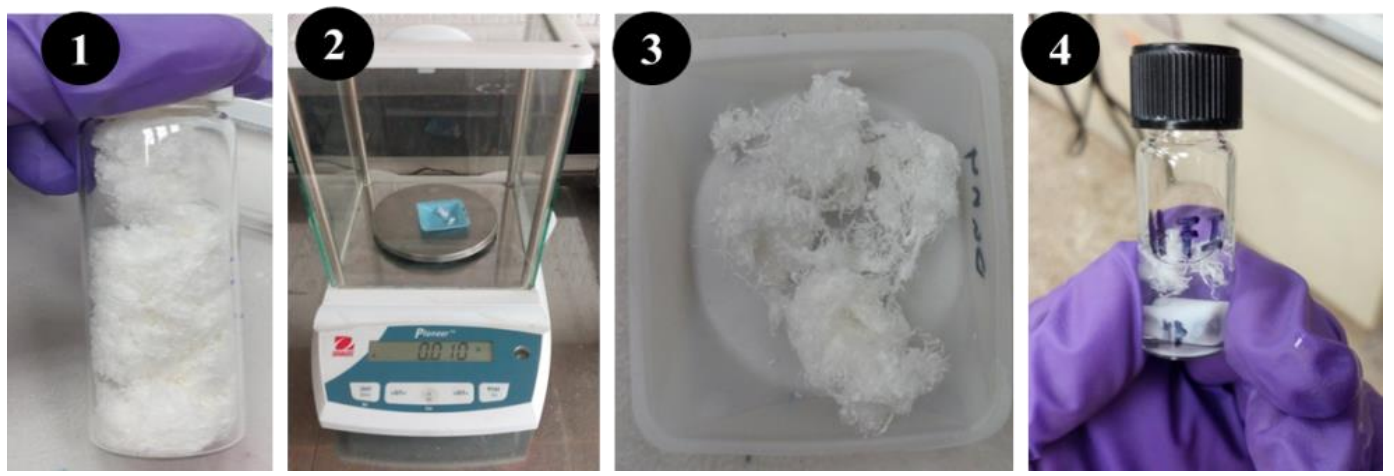

Fig. 3. Obtaining samples of cellulose. 1. Sugarcane cellulose, 2. Weighing the sample, 3. Cellulose fibers, 4. Cellulose with solvent.

\subsection{Preparation of solutions}

The cane cellulose samples were weighed and placed in each of the vials for each solvent (Fig. 4). 


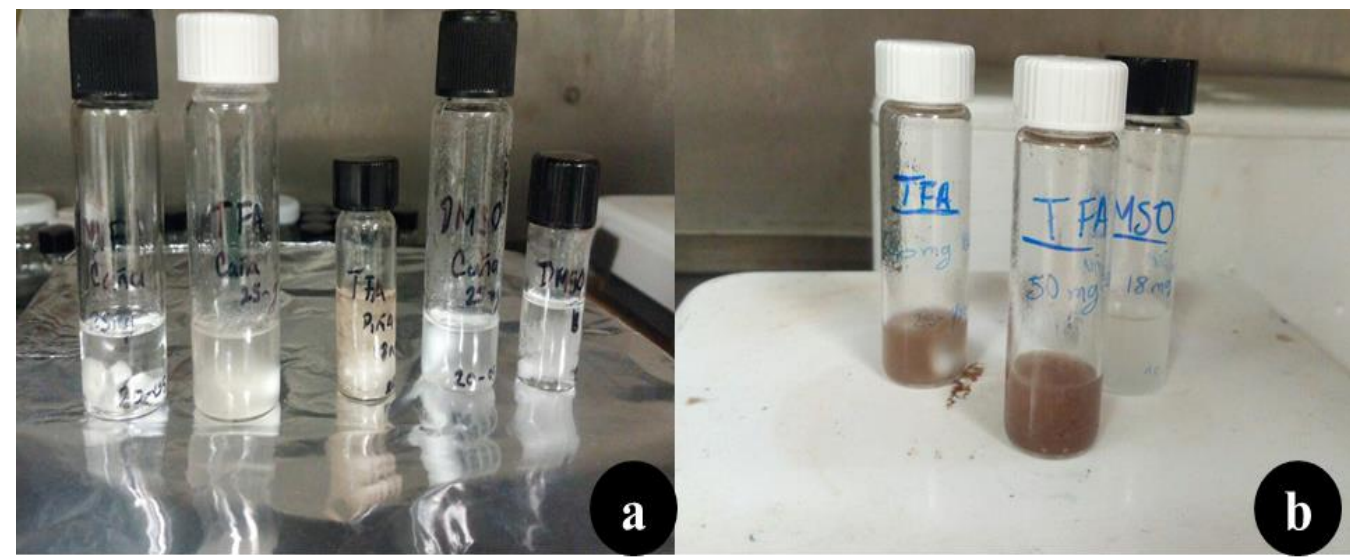

Fig. 4. Cellulose samples at $2.5 \%, 3.3 \%$ and $10 \%$, respectively, using TFA as solvent, with respect to $\mathrm{w} / \mathrm{v}$.

\subsection{Effect of the solution}

Only one of the tested solutions was able to dissolve the cellulose. The solvent group for cane cellulose showed many different behaviors. A summary of the macroscopic results obtained is shown in Table 1.

The ideal solution in which the solubility of the cellulose was reached was at a concentration of $10 \%$ w/v: $0.5 \mathrm{~g}$ cellulose / $5 \mathrm{ml}$ TFA. However, degradation was observed two days later.

Table 1. Parameters used in the different types of samples.

\begin{tabular}{lcccc}
\hline Sample & $\begin{array}{c}\text { Distance } \\
(\mathbf{c m})\end{array}$ & $\begin{array}{c}\text { Injection } \\
\text { flow } \\
(\mathbf{m l} / \mathbf{h})\end{array}$ & $\begin{array}{c}\text { Voltage } \\
(\mathbf{k V} / \mathbf{c m})\end{array}$ & $\begin{array}{c}\text { Concentration } \\
\mathbf{w} / \mathbf{v}\end{array}$ \\
\hline M001 & 15 & 0.4 & 15 & $2.5 \%$ \\
M002 & 15 & 0.4 & 13 & $2.5 \%$ \\
M003 & 10 & 0.4 & 15 & $2.5 \%$ \\
M004 & 15 & 0.4 & 15 & $3.3 \%$ \\
M005 & 15 & 0.4 & 12 & $3.3 \%$ \\
M006 & 15 & 0.2 & 15 & $3.3 \%$ \\
M007 & 15 & 0.4 & 15 & $5.0 \%$ \\
M008 & 15 & 0.1 & 14 & $5.0 \%$ \\
M009 & 10 & 0.1 & 14 & $5.0 \%$ \\
M010 & 15 & 0.4 & 14 & $10 \%$ \\
M011 & 10 & 0.4 & 14 & $10 \%$ \\
M012 & 12 & 0.4 & 14 & $10 \%$ \\
M013 & 10 & 0.4 & 14 & $10 \%$ \\
M014 & 10 & 0.4 & 14 & $10 \%$ \\
M015 & 10 & 0.4 & 15 & $10 \%$ \\
\hline
\end{tabular}




\subsection{Electro-spinning parameters}

The variables that were occupied in the electro-spinning were: the distance of the needle to the aluminum manifold, the injection speed of the solution and the potential difference generated between the electrodes. The parameters to be followed were: the voltage was varied from $10 \mathrm{kV}$ to $25 \mathrm{kV}$, the injection rate from $0.02 \mathrm{ml} / \mathrm{h}$ to $0.5 \mathrm{ml} / \mathrm{h}$ and the distance from 8 to $15 \mathrm{~cm}$.

Optimal conditions of distance, injection rate, voltage and relative humidity are presented in Table 2. These conditions were selected after analyzing the morphology images of the membranes obtained by light microscopy. The selected nanofibers had no defects and showed a homogeneous diameter.

Tabla 2. Optimal electro-spinning parameters

\begin{tabular}{cccc}
\hline \multicolumn{4}{c}{ Humidity 70\% } \\
\hline Distance & $\begin{array}{c}\text { Injection } \\
\text { flow } \\
(\mathrm{ml} / \mathrm{hr})\end{array}$ & $\begin{array}{c}\text { Voltage } \\
(\mathrm{kV})\end{array}$ & $\begin{array}{c}\text { Concentration } \\
\mathrm{w} / \mathrm{v}\end{array}$ \\
$\mathbf{1 5}$ & 0.25 & 16 & 5 \\
\hline
\end{tabular}

To control the humidity inside the equipment was placed a desiccant, so as not to interfere in the results, the average value of humidity was 30\%. In this case, it started with a humidity of $70 \%$ and to obtain an efficient electro-spinning, it was not possible to obtain it. However, the solution with the samples were very viscous and the humidity relatively high. To reduce the humidity, the silica (desiccant) was changed and a humidity of $48 \%$ was obtained.

It was observed that the membrane had finer fibers by allowing degradation of the solution, at concentrations of $2.5 \%, 3.3 \%$ and $5 \%$, no fibers were generated.

As mentioned above, the TFA solution was the one that was able to carry out the electrospinning, using the solution at a concentration of $10 \%$, however, more fiber was obtained in the membrane until the solution was degraded to the third day. Also, it is important to note that as the solution degraded the behavior of the fibers in the membrane was better and the fiber thickness decreased.

\subsection{Preparation of microfibers by electro-spinning}

During electro-spinning, we only experimented with a maximum voltage of $15 \mathrm{kV}$, at a distance of $10 \mathrm{~cm}$, since the increase in the equipment did not support more power (Table 3). 
Table 3. Suitable parameters for cellulose electro-spinning/10\% TFA.

\begin{tabular}{cccc}
\hline Distance & $\begin{array}{c}\text { Injection } \\
\text { flow } \\
(\mathbf{m l} / \mathbf{h r})\end{array}$ & $\begin{array}{c}\text { Voltage } \\
(\mathbf{k V})\end{array}$ & $\begin{array}{c}\text { Concentration } \\
\mathbf{w} / \mathbf{v}\end{array}$ \\
\hline $\mathbf{1 0} \mathbf{~ c m}$ & 0.4 & 15 & $10 \%$ \\
\hline
\end{tabular}

\section{DISCUSSION}

Nanofibers, today, are encompassing a large field in the field of health. They are nanometric structures with different shapes having a composition, similar characteristics and microscopic sizes. The National Science Foundation (NSF) considers that nanofibers have a diameter of less than $100 \mathrm{~nm}$. In order to obtain said nanofibers, techniques can be used which are known as electrodynamic techniques, in which electropulverization and electro-spinning are found. The latter is suitable for the production of nanofibers, which, although their equipment is simple and economical, have complex parameters that will be different for each type of polymer or material that is desired to be electro-polished, for which reason it is necessary to standardize the parameters for each type of material. The parameters that are measured in the technique can be classified into solution parameters (remembering that we can only electrolyte materials that dissolve or can melt) and parameters of the technique, within the first we find the concentration of the solution, the viscosity, Type of solvent, conductivity, surface tension, dielectric constant; Within the processing parameters we find type and material of manifold, as well as its distance from the needle containing the solution to be electro-polished, the diameter of the capillary nozzle, the flow velocity and the voltage that is used during the technique. Montini et al. (2015) reported that when applying a tension of 5-30 kV the polymer solution is strongly electrolyzed. Induced charges are generated which is distributed over the drop surface of the polymer solution hanging from a nozzle. Within our results the ideal voltage for our cellulose/TFA $10 \%$ solution was $15 \mathrm{kV}$, remembering that this parameter will depend on the type of solution being worked and the parameters mentioned above. The obtained membrane will be observed by SEM analysis in later investigations.

This technique has the possibility of producing membranes of various types of natural and synthetic polymers, this in conjunction with the properties of the nanofibers that make up the membranes open a wide range of applications for such materials, for example in the preparation of matrices for Tissue engineering and the development of membranes for the release of drugs; Has other applications in the industrial area such as the manufacture of fabrics, cleaning products and different types of filters.

During our process there was a need to allow the degradation of the solution, since by the chemical structure and thanks to the cellulose bonds (union of the hydroxyl glucoside group of carbon 1 of a molecule with the alcoholic hydroxyl group of carbon 4 of the Molecule next) the solution is very viscous, that it is almost impossible to charge the syringe and therefore, the passage through the capillary is impossible. This degradation is optimal at 8 days, before and after this it is very difficult to obtain the membrane, since after the eight days there is not enough polymer for the formation of the strand by total hydrolysis, only 
Glucose is contained. The cellulose has crystalline zones and amorphous zones that as its name indicate do not have an order as in the case of the former, these form parallel clusters together with longitudinal displacement, constituting the fibrils. The formation of these is due to the tendency to form hydrogen bonds between the alcoholic hydroxyls of the neighboring molecules, which is why it is difficult to dissolve our polymer.

Colin et al. (2013) reported that it is very difficult to obtain a membrane of a natural polymer, that for this it is necessary to incorporate some type of synthetic polymer to improve the spinability. But this would mean that the membrane does not have the characteristic of being $100 \%$ biodegradable, so in the present investigation we worked exclusively with sugarcane cellulose, extracted by the Cazaurang method. The electrospping process was not delayed and the results obtained were satisfactory, since we obtained nanofibers and cellulose membranes, therefore our product is $100 \%$ biodegradable and can be used for bioapplications. The properties of the fibers that are developed by the technique of electrospinning allow their use in areas such as tissue engineering where they mimic the functions of some tissues and controlled release of drugs in which they allow the timely delivery of medicines.

\section{ACKNOWLEDGMENTS}

We would like to thank Dr. Alfredo Maciel Cerda for his technical and academic support to carry out this project at the Institute for Materials Research (IIM-UNAM). This work was supported and financed by the Academic Mobility Agreement from the Chontalpa Popular University and the National Autonomous University of Mexico (UPCH-UNAM). We also thank the Tabasco State Council for Science and Technology (CCYTET) for providing a student scholarship.

\section{REFERENCES}

Beyer H. \& Walter W., 1987. Organic chemistry. Editorial Reverté. Barcelona. pp 977.

Cazaurang-Martínez N., S. Peraza-Sánchez \& C.A. Cruz-Ramos. 1990. Dissolving-grade pulps from henequen fibers. Cellulose Chemistry and Technology. 24: 629-638.

Colín Orozco, J., Zapata Torres, M., Pedroza Islas, R. \& Rodríguez Gattorno, G. 2013. Crecimiento y caracterización de nanofibras obtenidas a partir de proteína aislada de suero lácteo y oxido de polietileno por la técnica de electrohilado. Superficies y Vacío. Sociedad Mexicana de Ciencia y Tecnología de Superficies y Materiales. 26(2): 31-35.

Ciechanshka, D. 2004. Multifunctional bacterial cellulose/chitosan composite materials for medical application. Fibers \& Textiles in Eastern Europe. 12: 69-72.

Dersch R., Steinhart M., Boudriot U., Greiner A. \& Wendorff J.H. 2005. Nanoprocessing of Polymers: Applications in Medicine, Sensors, Catalysis, Photonics, Polymers for Advanced Technologies. 16: 276-282. 
Ege S. 2000. Organic chemistry: structure and reactivity. Volume II Editorial Reverté. Spain.

Huang C., Soenen SJ, Gulck EV., Vanham G., Rejman J, Calenbergh SV, Vervaet C, Coenye T., Verstraelen H., Temmerman M., Demeester J. \& De Smedt SC. 2012. Electrospun cellulose acetate phthalate fibers for semen induced anti-hiv vaginal drug delivery. Biomaterials. 33(3): 962-969.

Huang ZM, Zhang YZ, Kotaki M. \& Ramakrishna S. 2003. A review on polymer nanofibers by electro-spinning and their applications in nanocomposites. Composites Science and Technology. 63(15): 2223-2253.

Jiang H., Hu Y., Li Y, Zhao P, Zhu K. \& Chen W. 2005. A Facile Technique to Prepare Biodegradable coaxial electrospun nanofibers for controlled release of bioactive agents. Journal of Controlled Release. 108: 237-243.

Khil M.S., Bhattarai S.R., Kim HY, Kim SZ \& Lee KH. 2005. Novel fabricated matrix via electrospinning for tissue engineering. Journal of Biomedical Materials Research. 72(1): 117-124.

Li W., Caterson E, Tuan R \& Ko F. 2002. Electrospun nanofibrous structure a novel scaffold for tissue engineering. Journal of Biomedical Materials Research. 60(4): 613-621.

Li C., Vepari C., Jin HJ., Kim HJ. \& Kaplan DL. 2006. Electrospun silk-bmp-2 scaffolds for bone tissue engineering. Biomaterials. 27(16): 3115-3124.

Linstromberg W. 2006. Organic Chemistry. Editorial Reverté S. A. Encarnación, 86. Barcelona.

Montini F. \& Cortez P. 2015. Nanofibras Electrohiladas para Usos Terapéuticos. Módulo II: "Tecnologías aplicadas al diseño y producción de sistemas terapéuticos", En: Biomateriales Aplicados al Diseño de Sistemas Terapéuticos Avanzados (H. Souza, M. Braga, A. Sosnik, Editores). Coimbra University, Portugal. Capítulo 9, 385-417.

Muñoz M. \& Muraviev D. 2006. Development of new composite membranes for the separation of metallic ions and electrochemical applications. Autonomous University of Barcelona. pp 252.

Prashanth, K. V. H. \& Tharanathan, R. N. 2007. Chitin/chitosan: Modifications and their unlimited application potential. Department of biochemistry \& nutrition, Central Food Technological Research Institute. Mysore. 18:117-131.

Sill T.J. \& Von Recum H.A. 2008. Electrospinning: Applications in drug delivery and tissue engineering. Biomaterials. 29(13):1989-2006.

Smith L.A. \& Ma P.X. 2004. Nano-fibrous scaffolds for tissue engineering. Colloids and Surfaces B: Biointerfaces. 39(3):125-131. 
Yong Lee, K., Jeong L, Y. Ok Kang, Jin Lee S. \& Park W. H. 2009. Electrospinning of polysaccharides for regenerative medicine. Advanced Drug Delivery Reviews. 61(12):1020-1032. 